\title{
Synthesis, antibiotic structure-activity relationships, and cellulose dissolution studies of new room-temperature ionic liquids derived from lignin
}

\author{
Shihong Liu ${ }^{1,2}$, Michael Gonzalez ${ }^{1}$, Celine Kong ${ }^{3}$, Scott Weir $^{3}$ and Aaron M. Socha ${ }^{1,2^{*}}$ (])
}

\begin{abstract}
Background: lonic liquids (ILs) are promising pretreatment solvents for lignocellulosic biomass, but are largely prepared from petroleum precursors. Benzaldehydes from depolymerized lignin, such as vanillin, syringaldehyde, and 4-methoxy benzaldehyde, represent renewable feedstocks for the synthesis of ionic liquids. We herein report syntheses of novel lignin-derived ionic liquids, with extended $\mathrm{N}$-alkyl chains, and examine their melting points, cellulose dissolution capacities, and toxicity profiles against Daphnia magna and E. coli strain $1 \mathrm{~A} 1$. The latter organism has been engineered to produce isoprenol, a drop-in biofuel and precursor for commodity chemicals.
\end{abstract}

Results: The new N,N-diethyl and N,N-dipropyl methyl benzylammonium ILs were liquids at room temperature, showing $75-100{ }^{\circ} \mathrm{C}$ decreased melting points as compared to their $N, N, N$-trimethyl benzylammonium analog. Extension of $\mathrm{N}$-alkyl chains also increased antibacterial activity threefold, while ionic liquids prepared from vanillin showed 2- to 4-fold lower toxicity as compared to those prepared from syringaldehyde and 4-methoxybenzaldehyde. The trend of antibacterial activity for anions of lignin-derived ILs was found to be methanesulfonate $<$ acetate $<$ hydroxide. Microcrystalline cellulose dissolution, from 2 to $4 \mathrm{wt} \%$ after $20 \mathrm{~min}$ at $100^{\circ} \mathrm{C}$, was observed in all new ILs using light microscopy and IR spectroscopy.

Conclusions: Ionic liquids prepared from $\mathrm{H}$-, S- and G-lignin oxidation products provided differential cytotoxic activity against $E$. coli and D. magna, suggesting these compounds could be tailored for application specificity within a biorefinery.

\section{Background}

Ionic liquids (ILs) are salts with melting points below $100{ }^{\circ} \mathrm{C}$, super-solvents comprised entirely of paired ions. The physical properties of ILs, e.g., viscosity, conductivity, vapor pressure and thermal stability, are defined by structural features [1], and have been exploited in over 50 commercial applications [2]. Chemical "tuning" of

*Correspondence: sochaa@queens.edu

${ }^{1}$ Department of Chemistry and Environmental Science, Queens University of Charlotte, 1900 Selwyn Avenue, Charlotte, NC 28274, USA

Full list of author information is available at the end of the article ionic liquids has been described [3], exploited to solvate a wide range of natural products [4], and extended to protein stabilization [5] and enzyme catalysis [6]. Depending on their degree of basicity, ILs can dissolve cellulose [7], hemicellulose [8] and/or lignin [9], effectively pretreating plant biomass for enzymatic hydrolysis to monomeric sugars $[10,11]$. When compared to other biomass pretreatment methods, ILs typically provide higher spacetime yields of glucose and xylose [12, 13], and fewer inhibitors of downstream fermentation [14]. Bokinski et al. [15] demonstrated microbial production of butanol, fatty acid ester, and terpene biofuels from switchgrass 
pretreated with 1-ethyl-3-methyl imidazolium acetate (1). Integrated pretreatment and fermentation unit operations, using bio-based ILs, e.g., from amino acids [16, 17], have been demonstrated, as well as aqueous IL pretreatment systems using methanesulfonate anions [18]. Applications of ILs for the production of consumer products, such as textiles [19], and foods [20] have also garnered attention for bio-based ILs [21].

Mechanistic studies show IL toxicity generally increases with cation alkyl chain length as a result of cell membrane destabilization [22, 23]. $N$-alkylated pyridinium, imidazolium and quaternary ammonium cations showed increased toxicity across trophic levels, including studies with C. elegans, D. magna, and mammalian cell cultures [24-30]. Degree of functionalization of cation side chains [31], localization of heteroatoms on the cation and anion [28], cation and anion chain length [32,33], and/or ion coordination [34] can all influence bioactivity. Introduction of polar functional groups into shorter alkyl chains reduced the aquatic toxicity of a broad range of cation classes [35].

Quaternary ammonium ILs have diverse engineering applications [36], and have been listed as suitable COVID-19 disinfectants for hard, non-porous surfaces [37]. Our research focuses on biomass applications using benzylammonium ionic liquids and deep eutectic solvents synthesized from lignin depolymerization products, such as benzaldehydes [38-40], and we have recently demonstrated isolation techniques for aminophenol IL precursors from oxidized kraft lignin [41]. Diez et al. prepared a series of trimethyl benzylammonium acetate ILs (6-8) from 4-methoxy benzaldehyde, syringaldehyde, and vanillin, respectively, representing major oxidative depolymerization products from H-, S- and G-type lignin [39]. Though compounds 6-8 remained solid at room temperature, their utility as solvents for switchgrass pretreatment were comparable to $\mathbf{1}$. In the present study, modification of $N$-alkyl chains using diethyl and dipropyl amines provided room-temperature ILs 9-10. Cellulose solubility of the new compounds was examined using light microscopy and confirmed with IR spectroscopy.

In efforts to inform in planta lignin engineering of biorefinery feedstocks [42], the toxicity of the ligninderived ILs were determined using an E. coli strain recently optimized for the production of isoprenol (3-methyl-3-buten-1-ol) [43]. As commercial production volumes of ILs increase, there is a parallel risk of a leak or spill contaminating the environment, e.g., groundwater near a biorefinery. Therefore, selected ILs (11 and 12) were evaluated using Daphnia magna, a model organism used by the United States Environmental Protection Agency and the Organization for Economic Cooperation and Development to determine chemical contamination to freshwater environments $[44,45]$.

Of the lignin-derived ILs tested, those with elongated $\mathrm{N}$-alkyl chains showed greater antibacterial activity, and those prepared from vanillin displayed the lowest toxicity against both E. coli and D. magna (Fig. 1).

\section{Results and discussion \\ Synthesis of ionic liquids}

Compound 1 was obtained from BASF, and compounds 3 and 5 were purchased from Sigma Aldrich. Compounds $\mathbf{2}$ and $\mathbf{4}$ were prepared from compounds $\mathbf{3}$ and $\mathbf{5}$, respectively, using ion exchange. Compounds 6-8 were prepared using CBILS ${ }^{\mathrm{TM}}$ methyl carbonate chemistry as reported elsewhere [39]. Compounds $\mathbf{1 1}$ and $\mathbf{1 2}$ were synthesized from their corresponding methyl carbonates by ion exchange with methanesulfonic acid.

Synthesis of 9 was accomplished using the vanillin-derived benzylamine, 4-((diethylamino)methyl)2-methoxyphenol [40]. Bismethylation with methyl iodide provided the isolable intermediate, $N-(3,4-$ dimethoxybenzyl)- $N$-ethyl- $N$-methylethanaminium iodide. Lastly, 9 was achieved by ion exchange with silver acetate in $85 \%$ yield over 2 steps (Scheme 1a). Similarly, 10 was prepared from $N$-(3,4-dimethoxybenzyl)- $N$-propylpropan-1-amine using methyl iodide followed by silver acetate ( $77 \%$ yield over 2 steps) as shown in Scheme $1 \mathrm{~b}$. In contrast to $\mathbf{8}$, which formed a solid at room temperature, 9 and 10 remained liquid after extensive vacuum drying (Fig. 2). This result corresponds to those observed for short chain alkyl and hydroxyalkyl ammonium ILs, whereby increasing $N$-alkyl chain length decreases melting point [46].

\section{Cellulose dissolution experiments}

During biomass pretreatment with coordinating ILs, the crystalline nature of cellulose is often disrupted, providing downstream increases to saccharification rate and yield. Brønsted basic ILs provide hydrogen-bond-acceptor anions (e.g., carboxylate, dialkylphosphate, dialkylsulfonate) for cellulose hydroxyl groups, effectively swelling and/or solubilizing the cellulose polymer. Cellulose dissolution in quaternary ammonium ILs has been recently reviewed [47], showing a wide range of IL structures and cellulose solubilities, often involving co-solvents and catalysts (e.g., DMSO crown ethers). Neat tetraalkylammonium acetate ILs can dissolve approximately 2 wt\% $\alpha$-cellulose in $30 \mathrm{~min}$ at $100{ }^{\circ} \mathrm{C}$ [48]. Other systems, including $N, N$-allylmethylmorpholinium acetate, have shown up to $17 \mathrm{wt} \%$ dissolution of microcrystalline cellulose at $80^{\circ} \mathrm{C}$ for $20 \mathrm{~min}$ [49]. Low temperature, short residence time cellulose solubility studies with ammonium 

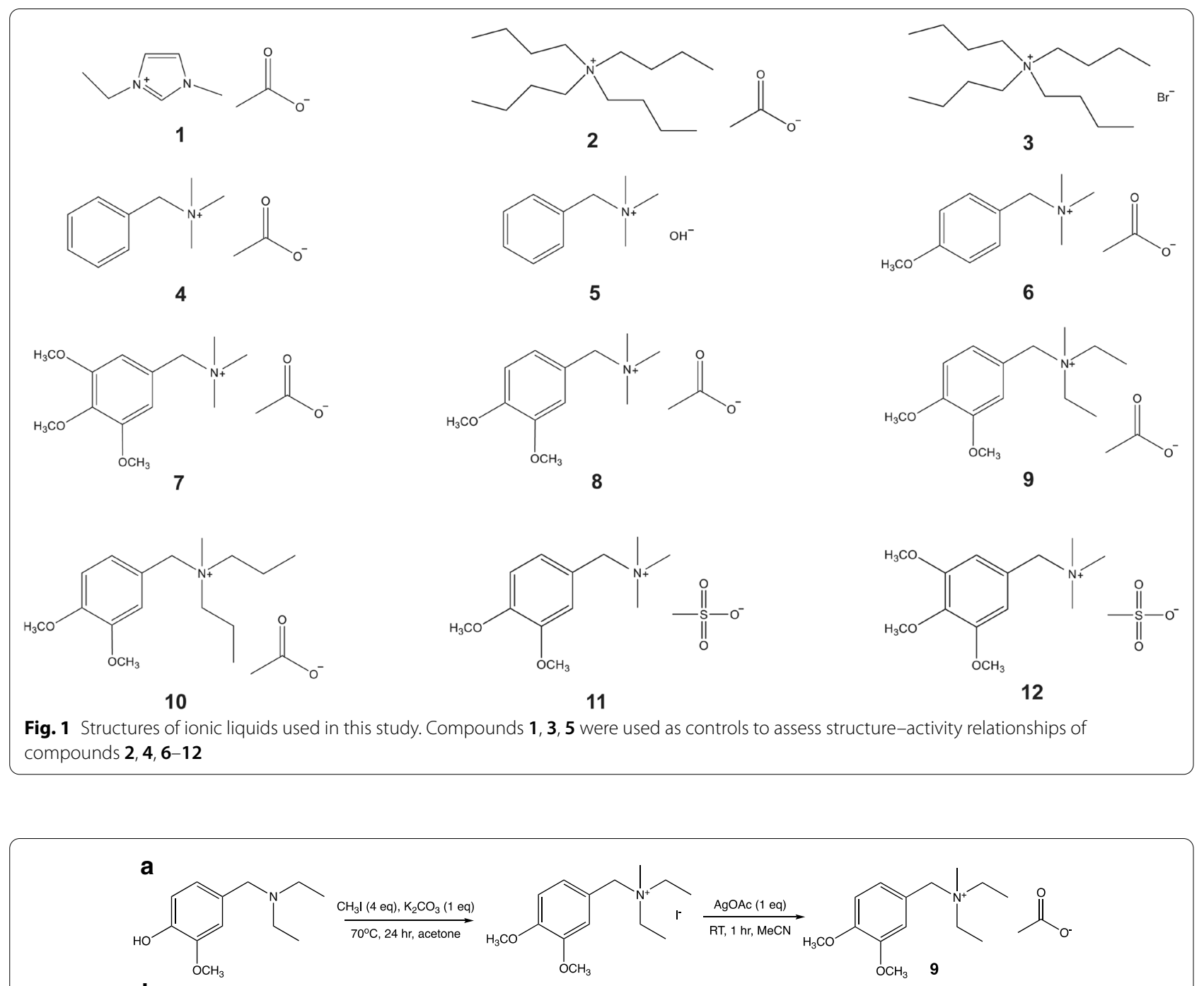

b

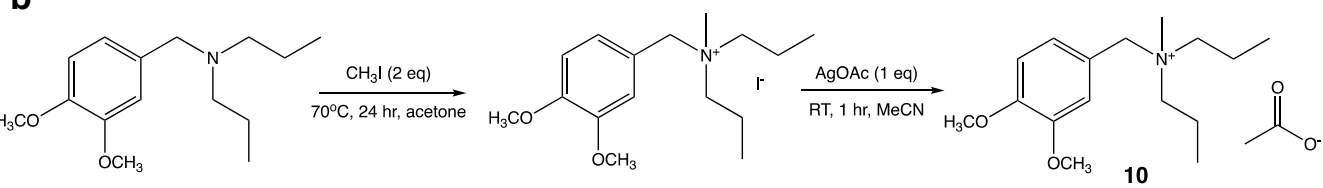

Scheme 1. The synthesis of room-temperature ILs $\mathbf{9}$ and $\mathbf{1 0}$ from vanillin-derived benzylamines

ILs are limited, and to our knowledge, do not include benzyl ammonium cations.

In this study, cellulose solubility in ILs 8-10 was determined gravimetrically, and light microscopy of ILs containing different concentrations of cellulose is provided in Fig. 3. For compound 8, cellulose precipitation was observed at $4 \mathrm{wt} \%$ at $120^{\circ} \mathrm{C}$, which is in good agreement with previous studies of compound 8 at $100{ }^{\circ} \mathrm{C}$ [39]. Cellulose precipitation was readily observed in compounds 9 and 10 at $2 \mathrm{wt} \%$ at $100{ }^{\circ} \mathrm{C}$. To further examine cellulose solubility, washed samples of cellulose precipitated from ILs 8-10 (2 wt\%) were centrifuged and analyzed by FTIR. For spectral comparison, untreated microcrystalline cellulose, and cellulose dissolved in $\mathbf{1}(10 \mathrm{wt} \%)$ were also analyzed, and are shown in Fig. 4.

The FTIR spectra show subtle, yet distinct differences between untreated cellulose and IL-treated cellulose. The broad absorbance from 3600 to $3100 \mathrm{~cm}^{-1}$, can be assigned to the stretching vibration of the $\mathrm{O}-\mathrm{H}$ covalent bond [50], and signal shift from $3333 \mathrm{~cm}^{-1}$ to $3407 \mathrm{~cm}^{-1}$ can be observed for cellulose recovered from ILs 1, 8, 10. These results agree with work performed by Ciolacu 


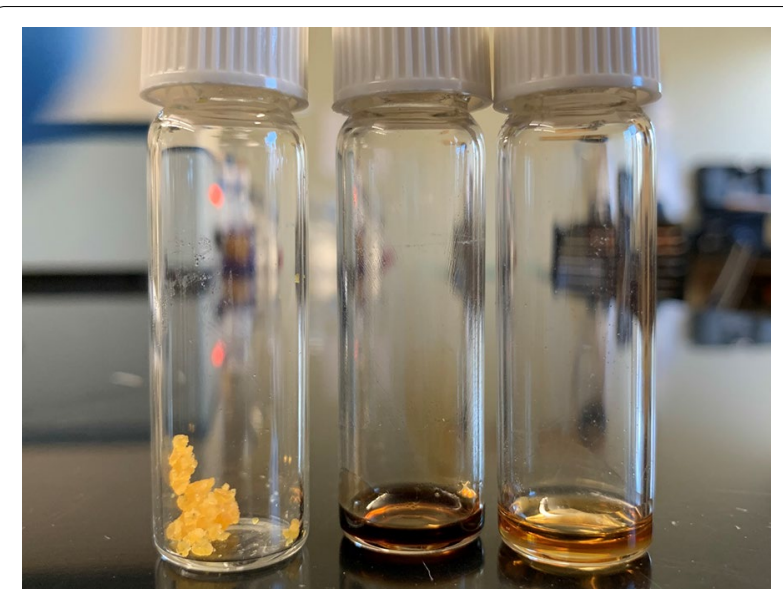

Fig. 2 Compounds 8-10 (left to right) after vacuum drying at $80{ }^{\circ} \mathrm{C}$ and 0.3 Torr for $1 \mathrm{~h}$ et al. [51], who reported similar wavenumber increases corresponding to disruption of intra- and intermolecular $\mathrm{H}$-bonds. The peak at $897 \mathrm{~cm}^{-1}$ represents $\mathrm{C}-\mathrm{O}-\mathrm{C}$ stretching at $\beta-(1-4)$-glycosidic linkages, an indicator for increased amorphous regions in the cellulose $[50,51]$. As shown in Fig. 4, the peak at $897 \mathrm{~cm}^{-1}$ displayed stronger intensity in cellulose dissolved in $\mathbf{1}, \mathbf{8}, \mathbf{1 0}$, and weaker intensity in untreated cellulose, and cellulose heated in $\mathbf{9}$.

The peaks at $1105 \mathrm{~cm}^{-1}$ and $1054 \mathrm{~cm}^{-1}$ are, respectively, assigned to $\mathrm{CH}$ stretching vibrations and $\mathrm{C}-\mathrm{O}-\mathrm{C}$ skeletal vibration of cyclic polysaccharides [50, 52]. It can be seen from Fig. 4 that the intensities of these signals are also related to decreased cellulose crystallinity. The peak intensity at $1105 \mathrm{~cm}^{-1}$ is decreased in all dissolved cellulose samples. Additionally, decreased signal intensity at $1054 \mathrm{~cm}^{-1}$ was clearly observed in all IL dissolved cellulose, except for compound 9. Lastly, the signal at $1031 \mathrm{~cm}^{-1}$, which is assigned to $\mathrm{C}-\mathrm{O}-\mathrm{C}$ stretching

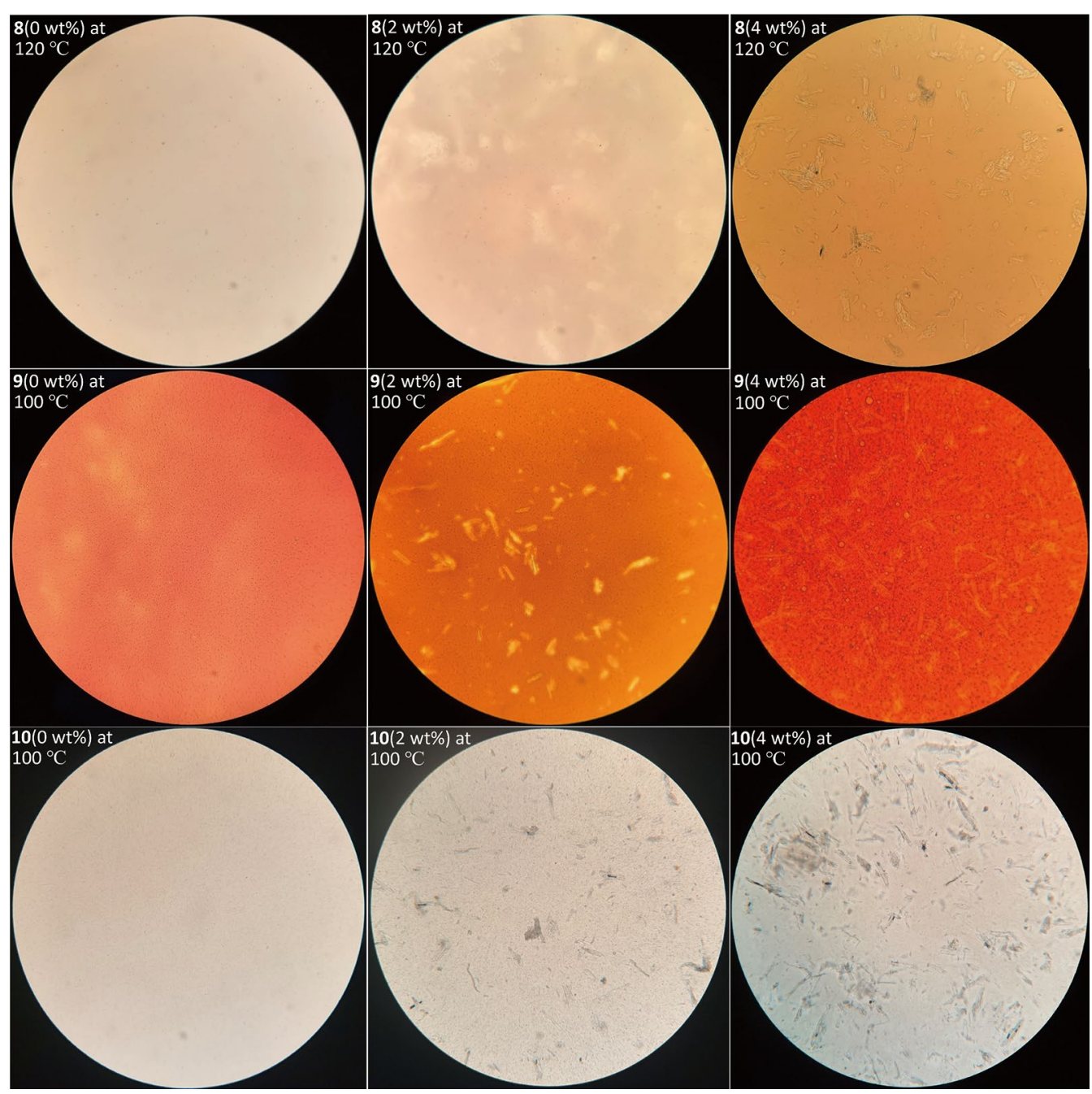

Fig. 3 Light microscopy (10x) of lignin-derived ILs 8-10 with increasing cellulose concentrations 


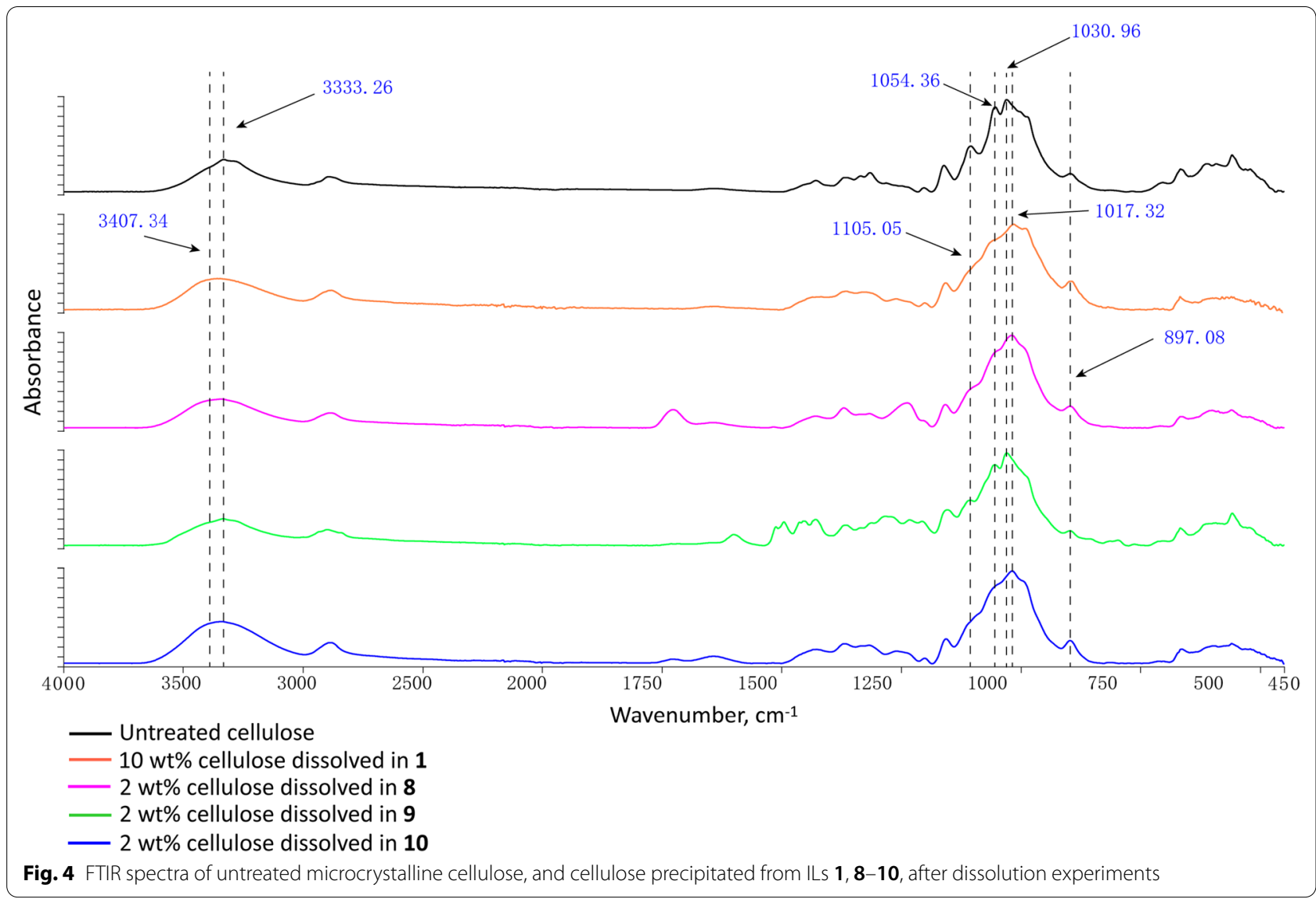

vibration for untreated cellulose [52], shifted to a lower wavenumber $\left(1017 \mathrm{~cm}^{-1}\right)$ in cellulose recovered from ILs $\mathbf{1}, \mathbf{8}$ and 10, yet this result is not observed in cellulose treated with 9.

Based on the results from Figs. 3 and 4, it can be concluded that lignin-derived ILs $\mathbf{8}$ and $\mathbf{1 0}$ had the greatest ability to dissolve and decrease the crystallinity of cellulose, under the temperature and time conditions tested. Among the selected lignin-derived ILs, 9 demonstrated slightly less effective cellulose dissolution and decrystallization, which may have arisen from minor, yet persistent impurities as observed in the ${ }^{1} \mathrm{H}$ NMR spectrum (Additional file 1: Figure S5).

\section{Antibiotic properties of selected ILs}

The results of broth dilution assays with $E$. coli are shown in Fig. 5 as inhibitory concentration of IL required to decrease bacterial growth by $50 \%\left(\mathrm{IC}_{50}\right)$. The results indicate that IL toxicity is a function of both cation and anion structure. As expected, increasing the cation side chain lengths from $N, N$-dimethyl (8), $N, N$-diethyl (9) or $N, N$ dipropyl (10) increased the toxicity approximately 2.5 fold. Compound $\mathbf{1 0}\left(\mathrm{IC}_{50}=17.7 \pm 0.9 \mathrm{mM}\right)$ gave a slightly greater toxicity than $9\left(\mathrm{IC}_{50}=19.6 \pm 0.4 \mathrm{mM}\right)$. This result can be explained by the increase of lipophilicity with the increase of the alkyl side chain length, which facilitates disruption of bacterial cell membranes. Though silver has well-known antibacterial properties, and is soluble in weakly coordinating ILs [53], washed ILs $\mathbf{9}$ and $\mathbf{1 0}$ did not show the characteristic signals of $\mathrm{Ag}^{+}$using ESIMS (Additional file 1: Figures S11-S13). Therefore, we conclude that the observed antibiotic activity is not due to the presence of residual silver in the ILs. Among the tetrabutylammonium ILs evaluated in this study, the acetate $\left(2, \mathrm{IC}_{50}=13.2 \pm 2.9 \mathrm{mM}\right)$ showed slightly less toxicity when compared to the bromide $\left(3, \mathrm{IC}_{50}=10.0 \pm 1.3 \mathrm{mM}\right.$, $p=0.055$ ), and the toxicity of tetrabutylammonium ILs were generally greater than that of the benzylammonium ILs (4, 6-10). Benzylammonium hydroxide (5) showed $\mathrm{IC}_{50}$ value of $10.4 \pm 0.3 \mathrm{mM}$, and gave a $\mathrm{pH}$ measurement of 8.5 at this concentration in LB media. To determine if the antibacterial activity of $\mathbf{5}$ was due to $\mathrm{pH}$ effects, an additional broth dilution assay was performed using sodium hydroxide as a positive control. The $\mathrm{IC}_{50}$ value of $\mathrm{NaOH}$ was measured at $25.5 \mathrm{mM} \pm 0.4 \mathrm{mM}$, and the $\mathrm{pH}$ of the LB media at this concentration was measured at 9.4. Therefore, $\mathrm{pH}$ was not the major cause of antibacterial activity for compound 5 . 


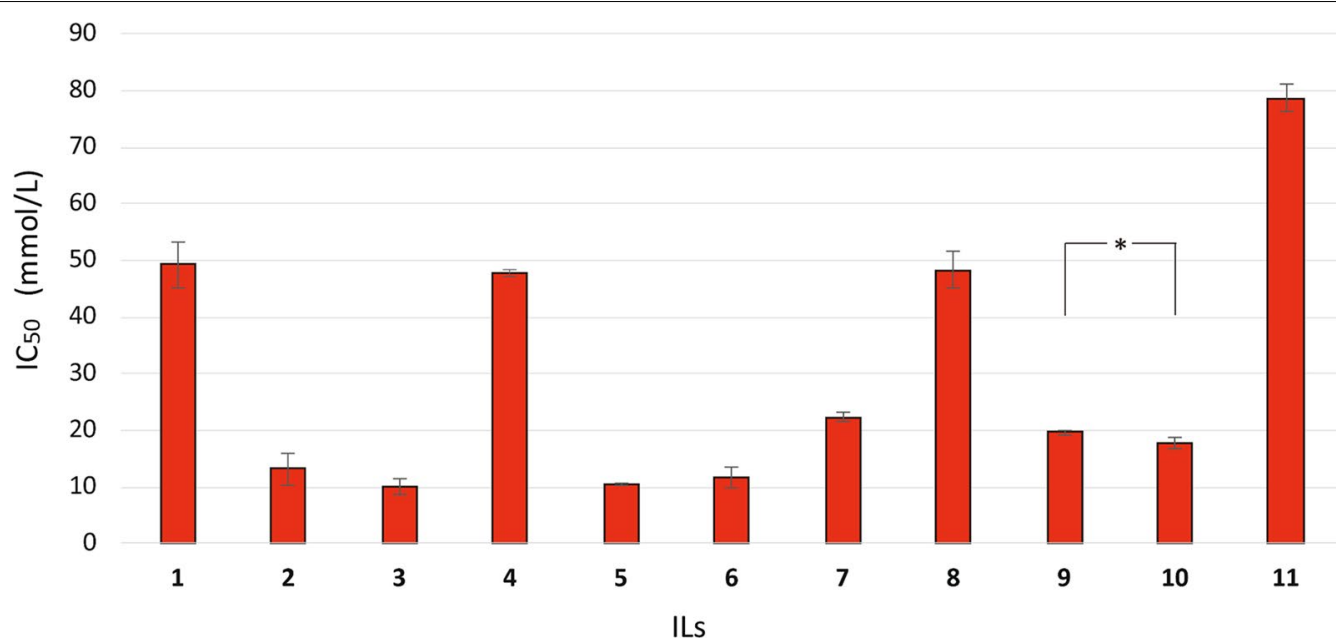

Fig. $5 \mid C_{50}$ of ILs tested on E. coli. Asterisk: statistically significant difference $(p=0.002, t=4.00)$ between $\mathbf{9}(n=7)$ and $\mathbf{1 0}(n=5)$

Interestingly, when holding the acetate anion, and the $\mathrm{N}, \mathrm{N}, \mathrm{N}$-trimethyl side chains of the cation constant, the toxicity of benzyl trimethylammonium ILs $(\mathbf{4}, \mathbf{6}-\mathbf{8})$ was modulated by the naturally occurring frequency and position of methoxy substitutions on the aromatic ring. A single methoxy substitution at the para position increased toxicity fourfold, as can be seen by comparing antibacterial values of compound $4\left(\mathrm{IC}_{50}=47.8 \pm 0.6 \mathrm{mM}\right)$ to $6\left(\mathrm{IC}_{50}=11.6 \pm 1.7 \mathrm{mM}\right)$. In compound 7 , derived from syringaldehyde, where methoxy groups are found in para and both meta positions, the $\mathrm{IC}_{50}$ value is $22.2 \pm 0.8 \mathrm{mM}$. In compound 8 , derived from vanillin, a methoxy group occupies the para and a single meta position, and the $\mathrm{IC}_{50}$ is $48.2 \pm 3.3 \mathrm{mM}$. The lignin-derived ILs are approximately 1000 -fold less toxic as compared to longer chain alkyl benzylammonium salts (e.g., $\mathrm{C}_{12}-\mathrm{C}_{16}$ ), such as those widely used as disinfectants, which give bactericidal concentrations between 1 and $150 \mu \mathrm{M}$ [54].

Anion type also affected the antibacterial activity of the lignin-derived ILs tested. Trimethyl benzylammonium acetate $\left(4, \mathrm{IC}_{50}=47.8 \pm 0.6 \mathrm{mM}\right)$ was found to be fourfold less toxic than its corresponding hydroxide (5, $\mathrm{IC}_{50}=10.4 \pm 0.3 \mathrm{mM}$ ). Holding the $N, N, N$-trimethyl vanillin-derived cation constant, introduction of a methanesulfonate anion $\left(\mathbf{1 1}, \mathrm{IC}_{50}=78.7 \pm 2.5 \mathrm{mM}\right)$ reduced toxicity 1.6-fold as compared to the acetate anion (8, $\left.\mathrm{IC}_{50}=48.2 \pm 3.3 \mathrm{mM}\right)$. Therefore, it can be concluded that the toxicity of anions showed a trend of methanesulfonate $<$ acetate $<$ hydroxide for $N, N, N$-trimethyl benzylammonium ILs. Similar results were obtained by Wood et al. [33], whereby ionic liquids prepared from alkylammonium cations and sulfate and sulfonate anions were found to be non-toxic in disk-diffusion assays using E. coli.
Analogous structure-activity relationships were observed from lignin-derived cations in acute toxicity assays with $D$. magna. The least antibacterial anion, methanesulfonate, was selected for evaluation, and paired with cations derived from G- and S-type lignin (11 and 12, respectively). Similar to the antibacterial trend, syringaldehyde-derived IL $12\left(\mathrm{IC}_{50}=0.123 \pm 0.012 \mathrm{mM}\right)$ was 2.6-fold more toxic to $D$. magna than vanillin-derived IL $11(0.319 \pm 0.066 \mathrm{mM})$. It should be noted that the $\mathrm{IC}_{50}$ of $11(0.319 \mathrm{mM})$ against $D$. magna is approximately 250-fold lower than its $\mathrm{IC}_{50}$ against $E$. coli $(78.7 \mathrm{mM})$ indicating that $D$. magna is far more sensitive to $\mathrm{N}, \mathrm{N}, \mathrm{N}$ trimethyl benzylammonium ILs. These data are in good agreement to reported values for $D$. magna $\left(\mathrm{IC}_{50} 0.1-\right.$ $0.5 \mu \mathrm{M}$ ), using longer chain (e.g., $\mathrm{C}_{12}-\mathrm{C}_{16}$ ) alkyl benzylammonium salts. [54]

\section{Conclusion}

The antibacterial effects of quaternary ammonium salts has been known for over a century, but increased production and usage during the COVID-19 pandemic [54] coupled to resistance in Gram-negative bacteria such as $P$. aeruginosa and $E$. coli [55] warrants investigation of bio-based alternatives. New synthetic approaches to lignin-derived quaternary ammonium compounds provided room-temperature ILs 9 and $\mathbf{1 0}$ that demonstrated rapid cellulose dissolution capacity at $100^{\circ} \mathrm{C}$. FTIR analysis confirmed that cellulose dissolution also reduced cellulose crystallinity. Broth dilution assays with ILs and $E$. coli suggested that antibacterial activity was due to both the structure of cations and type of anions. Anion toxicity followed the trend of methanesulfonate < acetate $<$ hydroxide. As compared to ILs derived from syringaldehyde and 4-methoxybenzaldehyde, asymmetric 
methoxy substitution on the benzyl ring of the cation may have reduced the toxicity of vanillin-derived ILs. The antibacterial mechanism of action for compounds 9 and 10 is likely due to IL disruption of the lipopolysaccharide cell membrane, as evidenced by the trend of increasing toxicity with increasing cation $N$-alkyl chain length. The reduced toxicity of ILs derived from vanillin (8, 11) against both $E$. coli and $D$. magna suggests that ILs derived from softwood lignin (G-type) could be favorable pretreatment solvents for biofuels produced with integrated fermentations, and/or bioproducts. These results warrant additional evaluation of room-temperature, lignin-derived ILs for biomass pretreatment, including lignin removal, effect on enzymatic saccharification and biodegradation.

\section{Methods}

NMR spectra were acquired by a Bruker Advance III HD spectrometer at the frequency of $400 \mathrm{MHz}$ for ${ }^{1} \mathrm{H}$ $\left(100 \mathrm{MHz}\right.$ for $\left.{ }^{13} \mathrm{C}\right)$. High-resolution mass spectrometry (HR-MS) was performed on an Agilent accuratemass 6520B Q-TOF mass spectrometer. A Perkin Elmer Spectrum Two FTIR spectrometer equipped with a universal diamond ATR unit was used for the analysis of dissolved cellulose. Spectra of samples were recorded between range of $450 \mathrm{~cm}^{-1}$ and $4500 \mathrm{~cm}^{-1}$, at a resolution of $4 \mathrm{~cm}^{-1}$. The spectra shown in Fig. 4 represent the accumulation of 4 scans/sample with baseline correction applied. All purchased chemicals were used without purification.

\section{Procedure for the synthesis of ILs 2, 4, 9 and 10.}

Tetrabutylammonium acetate (2) was prepared by dissolving tetrabutylammonium bromide (3) (322 mg, $1 \mathrm{mmol}, 1 \mathrm{eq}$ ) of in $20 \mathrm{~mL}$ of acetonitrile. Silver acetate (167 mg, $1 \mathrm{mmol}, 1 \mathrm{eq}$ ) was then added to the mixture. The reaction was allowed to stir at RT for $1 \mathrm{~h}$. After the reaction, the solution was centrifuged at $4000 \times \mathrm{G}$ for $10 \mathrm{~min}$, and the supernatant was collected and dried under vacuum $(0.3 \mathrm{Torr}, 1 \mathrm{~h})$ at $50{ }^{\circ} \mathrm{C}$. The product was obtained as a light yellow oil in $89 \%$ yield. ${ }^{1} \mathrm{H}$ NMR (acetone $\left.-d_{6}\right): 0.97(12 \mathrm{H}, \mathrm{t}), 1.41(8 \mathrm{H}, \mathrm{m}), 1.68(3 \mathrm{H}, \mathrm{s})$, $1.78(8 \mathrm{H}, \mathrm{m}), 3.48(8 \mathrm{H}, \mathrm{t}) .{ }^{13} \mathrm{C}$ NMR: $13.93,20.34,24.50$, 25.81, 59.14, 59.16, 174.47. HR-MS: $\left[\mathrm{C}_{16} \mathrm{H}_{36} \mathrm{~N}\right]^{+}$, found 242.2845, calcd. $242.2842(1.2 \mathrm{ppm})$. The ${ }^{1} \mathrm{H}$ and ${ }^{13} \mathrm{C}$ NMR of compound 2 are shown in Additional file 1: Figures S1, S2.

Benzyltrimethylammonium acetate (4) was prepared by mixing $418 \mathrm{mg}(1 \mathrm{mmol}, 1 \mathrm{eq})$ of benzyltrimethylammonium hydroxide $(5,40 \mathrm{wt} \%$ aqueous solution) with $60 \mathrm{mg}$ glacial acetic acid (1 mmol, $1 \mathrm{eq})$. The reaction was allowed to stir at RT for $1 \mathrm{~h}$. After the reaction, the solution was dried under vacuum $(0.3$ Torr, $1 \mathrm{~h})$ at $50{ }^{\circ} \mathrm{C}$.
The product was obtained as a clear liquid in quantitative yield. ${ }^{1} \mathrm{H}$ NMR $\left(\mathrm{D}_{2} \mathrm{O}\right): 1.86(3 \mathrm{H}, \mathrm{s}), 3.06(9 \mathrm{H}, \mathrm{s}), 4.44$ $(2 \mathrm{H}, \mathrm{s}), 7.52(5 \mathrm{H}, \mathrm{m}) .{ }^{13} \mathrm{C}$ NMR: 23.42, 52.36, 52.40, 52.44, 69.63, 127.43, 129.25, 130.90, 132.86, 181.29. HR-MS: $\left[\mathrm{C}_{10} \mathrm{H}_{16} \mathrm{~N}\right]^{+}$, found 150.1278, calcd. 150.1277 (0.7 ppm). The ${ }^{1} \mathrm{H}$ and ${ }^{13} \mathrm{C}$ NMR of compound 4 are shown in Additional file 1: Figures S3, S4.

$N$-(3,4-Dimethoxybenzyl)- $N$-ethyl- $N$-methylethanaminium acetate (9) was prepared by dissolving $209 \mathrm{mg}$ (1 mmol, $1 \mathrm{eq})$ of 4-((diethylamino)methyl)-2-methoxyphenol in $2 \mathrm{~mL}$ of acetone. Dry $\mathrm{K}_{2} \mathrm{CO}_{3}(138 \mathrm{mg}, 1 \mathrm{mmol}$, $1 \mathrm{eq})$ was added, followed by methyl iodide $(568 \mathrm{mg}$, $4 \mathrm{mmol}, 4 \mathrm{eq})$. The reaction was kept at $70{ }^{\circ} \mathrm{C}$ for $24 \mathrm{~h}$. After the reaction, the solution was filtered and then dried under vacuum $(0.3$ Torr, $1 \mathrm{~h})$ at $50{ }^{\circ} \mathrm{C}$. The product was then re-dissolved in $20 \mathrm{~mL}$ of acetonitrile and mixed with silver acetate (167 mg, $1 \mathrm{mmol}, 1 \mathrm{eq})$. After $1 \mathrm{~h}$ of reaction at $\mathrm{RT}$, the solution was centrifuged at $4000 \times \mathrm{G}$ for $10 \mathrm{~min}$, and the supernatant was collected and dried under vacuum $(0.3$ Torr, $1 \mathrm{~h})$ at $50{ }^{\circ} \mathrm{C}$. To ensure the complete removal of the insoluble silver salts, the dried product was washed with $10 \mathrm{~mL}$ of methanol and then filtered through $0.25 \mathrm{~mm}$ syringe filter. The filtrate was then dried under vacuum $(0.3 \mathrm{Torr}, 1 \mathrm{~h})$ at $50{ }^{\circ} \mathrm{C}$. The final product was obtained as a dark brown oil in $85 \%$ overall yield. ${ }^{1} \mathrm{H}$ NMR (DMSO- $d_{6}$ with $1 \mu \mathrm{L}$ acetone as calibration standard): $1.19(6 \mathrm{H}, \mathrm{t}), 1.73(3 \mathrm{H}, \mathrm{s}), 2.96(6 \mathrm{H}$, s), $3.29(4 \mathrm{H}, \mathrm{q}), 3.71(3 \mathrm{H}, \mathrm{m}), 4.91(2 \mathrm{H}, \mathrm{m}), 6.86(3 \mathrm{H}, \mathrm{m})$. ${ }^{13}$ C NMR: 7.42, 24.29, 48.52, 55.17, 56.66, 57.54, 73.71, $112.17,115.04,120.40,127.22,147,41,147.53,173.10$. HR-MS: $\left[\mathrm{C}_{14} \mathrm{H}_{24} \mathrm{NO}_{2}\right]^{+}$, found 238.1803, calcd. 238.1802 (0.4 ppm). The ${ }^{1} \mathrm{H}$ and ${ }^{13} \mathrm{C}$ NMR of compound 9 are shown in Additional file 1: Figures S5, S6.

$N$-(3,4-Dimethoxybenzyl)- $N$-propylpropan-1-amine was prepared by dissolving 3,4-dimethoxybenzaldehyde $(10.0 \mathrm{~g}, 60 \mathrm{mmol}, 1 \mathrm{eq})$ into $200 \mathrm{~mL}$ dry acetonitrile. While stirring, dipropylamine (7.92 g, $78 \mathrm{mmol}, 1.3 \mathrm{eq})$ was added followed by sodium triacetoxyborohydride (17.85 g, $84.2 \mathrm{mmol}, 1.4 \mathrm{eq})$. The reaction was allowed to stir at RT overnight and worked up as reported elsewhere [38]. After vacuum drying $(0.3$ Torr, $1 \mathrm{~h})$ at $50^{\circ} \mathrm{C}$, the product $(14.1 \mathrm{~g}, 55.8 \mathrm{mmol})$ was obtained as a pale yellow oil in $93 \%$ yield. ${ }^{1} \mathrm{H}$ NMR $\left(\mathrm{CDCl}_{3}\right): 0.86(6 \mathrm{H}, \mathrm{t})$, $1.49(4 \mathrm{H}, \mathrm{m}), 2.40(4 \mathrm{H}, \mathrm{t}), 3.53(2 \mathrm{H}, \mathrm{s}), 3.86(3 \mathrm{H}, \mathrm{s}), 3.88$ $(3 \mathrm{H}, \mathrm{s}), 6.79(2 \mathrm{H}, \mathrm{m}), 6.99(1 \mathrm{H}, \mathrm{s}) .{ }^{13} \mathrm{C}$ NMR: 11.99, 19.97, 55.61, 55.94, 55.98, 58.40, 110.76, 112.09, 120.92, 148.01, 148.95. HR-MS: $\left[\mathrm{C}_{15} \mathrm{H}_{26} \mathrm{NO}_{2}\right]^{+}$, found 252.1955 , calcd. for 252.1958 (1.2 ppm). The ${ }^{1} \mathrm{H}$ and ${ }^{13} \mathrm{C}$ NMR of $N-(3,4-$ dimethoxybenzyl)- $N$-propylpropan-1-amine are shown in Additional file 1: Figures S7, S8.

$N$-(3,4-Dimethoxybenzyl)- $N$-methyl- $N$-propylpropan1-ammonium acetate (10) was prepared by dissolving $N$-(3,4-dimethoxybenzyl)- $N$-propylpropan-1-amine 
(325 $\mathrm{mg}, 1 \mathrm{mmol}$ ) in $2 \mathrm{~mL}$ of acetone. Methyl iodide ( $284 \mathrm{mg}, 2 \mathrm{mmol}, 2 \mathrm{eq}$ ) was then added to the mixture. The reaction was kept at $70{ }^{\circ} \mathrm{C}$ for $24 \mathrm{~h}$. After the reaction, the solution was filtered and dried under vacuum $(0.3$ Torr, $1 \mathrm{~h})$ at $50{ }^{\circ} \mathrm{C}$, and the product was then re-dissolved in $20 \mathrm{~mL}$ of acetonitrile and mixed with silver acetate (167 mg, $1 \mathrm{mmol}, 1 \mathrm{eq})$. After $1 \mathrm{~h}$ of reaction at RT, the solution was centrifuged at $4000 \times \mathrm{G}$ for $10 \mathrm{~min}$, and the supernatant was collected and dried under vacuum $(0.3$ Torr, $1 \mathrm{~h})$ at $50{ }^{\circ} \mathrm{C}$. To ensure the complete removal of the insoluble silver salts, the dried product was washed with $10 \mathrm{~mL}$ of methanol and then filtered through $0.25 \mathrm{~mm}$ syringe filter. The filtrate was then dried under vacuum $(0.3$ Torr, $1 \mathrm{~h})$ at $50{ }^{\circ} \mathrm{C}$. The final product was obtained as a dark brown oil in $77 \%$ overall yield. ${ }^{1} \mathrm{H}$ NMR: $0.89(6 \mathrm{H}, \mathrm{t}), 1.60(3 \mathrm{H}, \mathrm{s}), 1.75(4 \mathrm{H}, \mathrm{m}), 2.92(3 \mathrm{H}, \mathrm{s})$, 3.14 (4H, m), 3.78 (6H, s), 4.52(2H, s), $7.09(3 \mathrm{H}, \mathrm{m}) .{ }^{13} \mathrm{C}$ NMR (DMSO- $d_{6}$ ): 10.58, 15.28, 25.58, 46.82, 48.43, 55.51, 55.67, 61.31, 64.44, 111.54, 116.34, 120.18, 125.90, 148.54, 150.12, 173.18. HR-MS: $\left[\mathrm{C}_{16} \mathrm{H}_{28} \mathrm{NO}_{2}\right]^{+}$, found 266.2118, calcd. 266.2115 (1.1 ppm). The ${ }^{1} \mathrm{H}$ and ${ }^{13} \mathrm{C}$ NMR of compound $\mathbf{1 0}$ are shown in Additional file 1: Figures S9, S10.

\section{Cellulose dissolution}

Avicel PH 101 microcrystalline cellulose obtained from Sigma Aldrich was used in the dissolution experiments. To test cellulose solubility, $500 \mathrm{mg}$ of selected ILs were collected in a $7 \mathrm{~mL}$ transparent glass tube and heated in a sand bath at $100{ }^{\circ} \mathrm{C}$ for $1 \mathrm{~h}$ (compound 8 was heated to $120^{\circ} \mathrm{C}$ for $1 \mathrm{~h}$ for due to its higher melting point). Cellulose (10 $\mathrm{mg}, 2 \mathrm{wt} \%$ ) was added slowly into the tube, and the solution was stirred with a spatula. After $20 \mathrm{~min}$ of incubation, a drop of the solution was taken and observed under a light microscope $(10 \times$ magnification $)$. The procedure was repeated with $20 \mathrm{mg}$ (4\%) of total cellulose addition.

\section{FTIR spectroscopy of dissolved cellulose}

The IL solutions with $2 \mathrm{wt} \%$ cellulose concentration were used for FTIR analysis. Methanol $(5 \mathrm{~mL})$ was added into the tube to dissolve the IL and precipitate the dissolved cellulose. The solution was then transferred to a $50 \mathrm{~mL}$ centrifuge tube and centrifuged at $4000 \times \mathrm{G}$ for $10 \mathrm{~min}$. After removal of the supernatant, the cellulose at bottom was dried in an oven at $70{ }^{\circ} \mathrm{C}$ for $1 \mathrm{~h}$ before FTIR analysis.

\section{Antibiotic assays}

E. coli strain 1A1 [43] was obtained from the microbial strain repository at the Joint Bioenergy Institute at Lawrence Berkeley National Laboratory. A $10 \mathrm{~mL}$ culture in Luria Broth (LB) media was grown for $18 \mathrm{~h}$ at $37{ }^{\circ} \mathrm{C}$ with shaking at $200 \mathrm{rpm}$. The culture was then diluted into LB media to an absorbance of 0.05 at $600 \mathrm{~nm}$, and added into the wells of a 96-well plate (first row $=190$ $\mu \mathrm{L}$, all other wells $=100 \mu \mathrm{L} /$ well). Approximately $700 \mathrm{mg}$ of IL was dissolved into $1 \mathrm{~mL}$ of methanol, and $10 \mu \mathrm{L}$ of each IL solution was added to first row wells of the plate. A twofold serial dilution was performed down the plate by mixing and transferring $100 \mu \mathrm{L}$ using a multi-channel pipette. To maintain isochoric conditions, $100 \mu \mathrm{L}$ was discarded from bottommost wells. The plate was then incubated at $37{ }^{\circ} \mathrm{C}$ with shaking at $150 \mathrm{rpm}$. After $24 \mathrm{~h}$ incubation, $E$. coli growth was quantified at $600 \mathrm{~nm}$ using an Epoch Microplate Spectrophotometer (Gen5 software). Cells grown with $10 \mu \mathrm{L}$ of methanol were used as negative controls, and resulted in zero growth inhibition. All experiments were repeated 3-7 times and error bars in Fig. 5 represent standard deviation. Statistical F-test was performed to determine the appropriate t-test (i.e., equal or unequal variance) to analyze significant difference between $\mathrm{IC}_{50}$ data.

\section{Daphnia magna cultivation}

Procedures for cultivating and performing acute toxicity assays with $D$. magna generally followed the US EPA protocol [56]. Daphnia magna was cultured from stocks supplied by Aquatic Bio Systems Inc. (Fort Collins, CO). The organisms were cultured in $900-\mathrm{mL}$ jars filled with moderately hard water from the recipe: $0.473 \mathrm{~g} \mathrm{CaSO}_{4}$, $0.959 \mathrm{~g} \mathrm{NaHCO}_{3}, 1.223 \mathrm{~g} \mathrm{MgSO}_{4} \cdot 7 \mathrm{H}_{2} \mathrm{O}$, and $0.039 \mathrm{~g} \mathrm{KCl}$ per $10 \mathrm{~L}$ of deionized water. $2 \mathrm{~mL}$ of algae (Selenastrum capriconutum) containing $3.0 \times 10^{7}$ cells $/ \mathrm{mL}$ were fed to D. magna on both Tuesdays and Thursdays with water changes as well as feedings on Saturdays. All glass jars were placed in a Thermo Scientific Precision incubator (Fischer Scientific, Hampton, $\mathrm{NH}$ ) at a holding temperature of $20^{\circ} \mathrm{C}$ and on a $12 \mathrm{~h}: 12 \mathrm{~h}$ light:dark cycle. This procedure was conducted approximately a month prior to the beginning of the project. To prepare D. magna for use in acute experiments, three hundred adult daphnids were separated into five 1-L beakers with 60 daphnids each. These daphnids were used a week later in the experiment. All daphnid cultures followed the same protocol for feeding and water changes as mentioned previously.

\section{Acute toxicity study of ILs on D. magna}

A 48-h acute toxicity study was carried out to examine the toxic effects of $\mathbf{1 1}$ and $\mathbf{1 2}$ on D. magna, Glass jars were filled with moderately hard water and spiked with the appropriate concentration of IL from stock solution to a total volume of $50 \mathrm{~mL}$. For each IL, 5 different concentrations were studied. Control jars were set up with only $50 \mathrm{~mL}$ of moderately hard water. Four replicates were used for each concentration and each replicate had four daphnids. The daphnids were placed into glass jars for each concentration of ILs. All glass jars were placed 
in a Thermo Scientific Precision incubator (Fischer Scientific, Hampton, $\mathrm{NH}$ ) at a holding temperature of $20^{\circ} \mathrm{C}$ and on a $12 \mathrm{~h}: 12 \mathrm{~h}$ light:dark cycle. Mortality in each jar was recorded every $24 \mathrm{~h}$.

\section{Supplementary Information}

The online version contains supplementary material available at https://doi. org/10.1186/s13068-021-01898-x.

Additional file 1. Fig. S1. ${ }^{1} \mathrm{H}$ NMR spectrum of compound $\mathbf{2}$ dissolved in acetone- $d_{6}$ containing TMS (400 MHz). Fig. $\mathbf{S 2}{ }^{13} \mathrm{C}$ NMR spectrum of compound $\mathbf{2}$ dissolved in acetone- $\mathrm{d}_{6}$ containing TMS (400 MHz). Fig. $\mathbf{S 3}$ ${ }^{1} \mathrm{H}$ NMR spectrum of compound $\mathbf{4}$ dissolved in $\mathrm{D}_{2} \mathrm{O}(400 \mathrm{MHz})$. Fig. $\mathbf{S 4}$ ${ }^{13} \mathrm{C}$ NMR spectrum of compound $\mathbf{4}$ dissolved in $\mathrm{D}_{2} \mathrm{O}(400 \mathrm{MHz})$. Fig. $\mathbf{S 5}$ ${ }^{1} \mathrm{H}$ NMR spectrum of compound $\mathbf{9}$ dissolved in DMSO- $\mathrm{d}_{6}(400 \mathrm{MHz})$. Fig. S6 ${ }^{13} \mathrm{C}$ NMR spectrum of compound 9 dissolved in DMSO- $\mathrm{d}_{6}(400 \mathrm{MHz})$. Fig. $\mathbf{S 7}{ }^{1} \mathrm{H}$ NMR spectrum of N-(3,4-dimethoxybenzyl)-N-propylpropan1-amine dissolved in $\mathrm{CDCl}_{3}(400 \mathrm{MHz})$. Fig. $\mathbf{S 8}{ }^{13} \mathrm{C}$ NMR spectrum of $\mathrm{N}$-(3,4-dimethoxybenzyl)-N-propylpropan-1-amine dissolved in $\mathrm{CDCl}_{3}(400$ $\mathrm{MHz}$. Fig. $\mathbf{5 9}{ }^{1} \mathrm{H}$ NMR spectrum of compound 10 dissolved in DMSO-d 6 (400 MHz). Fig. S10 ${ }^{1} 3 \mathrm{C}$ NMR spectrum of compound 10 dissolved in DMSO-d 6 (400 MHz). Fig. S11 Low molecular weight regions of ESI-MS spectra for compound $\mathbf{9}$ in positive ion mode showing the absence of residual $\mathrm{Ag}^{+}$ion. Fig. $\mathbf{S 1 2}$ Low molecular weight regions of ESI-MS spectra for compound $\mathbf{1 0}$ in positive ion mode showing the absence of residual $\mathrm{Ag}^{+}$ion. Fig. S13 ESI-MS spectrum of control spectrum showing $\mathrm{Ag}^{+}$ signals at $106.9047(100 \%)$ and $108.9043(92.9 \%)$.

\section{Acknowledgements}

The authors would like to thank Dr. Taek Soon Lee (Lawrence Berkeley National Lab) for his generous gift of E. coli strain 1A1, Dr. David Blauch (Davidson College) for obtaining NMR and HR-MS measurements on the new compounds, and Mr. Baptiste Leger for his assistance with D. magna assays.

\section{Authors' contributions}

AS and SL conceived of the study, designed the experiments, examined all spectroscopic data and wrote the manuscript. SL performed all synthesis, cellulose dissolution experiments, microscopy and spectroscopy. SL and MG performed all antibacterial assays and performed statistical analysis of the data. SW and CK designed and performed all assays with D. magna and SW assisted with statistical analysis of antibacterial data. All authors read and approved the final manuscript.

\section{Funding}

Financial support for this project was provided by the Bioenergy Technologies Office within the DOE Energy Efficiency and Renewable Energy Office. Support for undergraduate research for MG was provided by NSF Advanced Technical Education Award 1601636.

\section{Availability of data and materials}

Data and materials used in this study are available upon request.

\section{Ethics approval and consent to participate}

Not applicable.

\section{Consent for publication}

The views expressed in the article do not necessarily represent the views of the DOE or the U.S. Government. The U.S. Government, and the publisher, by accepting the article for publication, acknowledge that the U.S. Government retains a nonexclusive, paid-up, irrevocable, worldwide license to publish or reproduce the published form of this work or allow others to do so, for U.S. Government purposes.

\section{Competing interests}

The authors declare no competing interests.

\section{Author details}

${ }^{1}$ Department of Chemistry and Environmental Science, Queens University of Charlotte, 1900 Selwyn Avenue, Charlotte, NC 28274, USA. ${ }^{2}$ Biological Systems and Engineering Division, Lawrence Berkeley National Laboratory, Berkeley, CA, USA. ${ }^{3}$ Department of Biology, Queens University of Charlotte, 1900 Selwyn Avenue, Charlotte, NC 28274, USA.

Received: 16 December 2020 Accepted: 8 February 2021

Published online: 23 February 2021

\section{References}

1. Zhang S, Lu X, Zhou Q, Li X, Zhang X, Li S. In: Ionic Liquids (Physicochemical Properties). Amsterdam: Elsevier; 2009.

2. Kalb RS. Toward Industrialization of Ionic Liquids. In: Shiflett M, editor. Commercial Applications of Ionic Liquids. Green Chemistry and Sustainable Technology. Cham: Springer; 2020. p. 261-82.

3. Davis JH. Task-specific ionic liquids. Chem Lett. 2004;33:1072-7.

4. Ventura SPM, Silva FAR, Quental MV, Mondal D, Freire MG, Coutinho JAP. Ionic-liquid-mediated extraction and separation processes for bioactive compounds: past, present, and future trends. Chem Rev. 2017;117:6984-7052.

5. Fujita K, Forsyth M, MacFarlane DR, Reid RW, Elliott GD. Unexpected improvement in stability and utility of cytochrome $\mathrm{c}$ by solution in biocompatible ionic liquids. Biotechnol Bioeng. 2006;94:1209-13.

6. Roosen C, Müller P, Greiner L. Ionic liquids in biotechnology: Applications and perspectives for biotransformations. Appl Microbiol Biotechnol. 2008;81:607-14.

7. Swatloski RP, Spear SK, Holbrey JD, Rogers RD. Dissolution of cellulose with ionic liquids. J Am Chem Soc. 2002;124:4974-5.

8. Ohno H, Fukaya Y. Task specific ionic liquids for cellulose technology. Chem Lett. 2009;38:1.

9. Sun N, Parthasari R, Socha AM, Shi J, Zhang S, Stavila V, Sale KL, Simmons BA, Singh S. Understanding pretreatment efficacy of four cholinium and imidazolium ionic liquids by chemistry and computation. Green Chem. 2014;16:2546-57.

10. Brandt A, Gräsvik J, Hallett JP, Welton T. Deconstruction of lignocellulosic biomass with ionic liquids. Green Chem. 2013;15:550-83.

11. Li C, Liang L, Sun N, Thompson VS, Xu F, Narani A, He Q, Tanjore D, Pray TR, Simmons BA, Singh S. Scale-up and process integration of sugar production by acidolysis of municipal solid waste/corn stover blends in ionic liquids Biotechnol. Biofuels. 2017;10:13.

12. Li C, Knierim B, Manisseri C, Arora R, Scheller HV, Auer M, Vogel KP, Simmons BA, Singh S. Comparison of dilute acid and ionic liquid pretreatment of switchgrass: Biomass recalcitrance, delignification and enzymatic saccharification. Bioresour Technol. 2010;101:4900-6.

13. Uppugundla N, Da Costa SL, Chundawat SPS, Yu X, Simmons B, Singh S, Gao X, Kumar R, Wyman CE, Dale BE, Balan V. A comparative study of ethanol production using dilute acid, ionic liquid and AFEXTM pretreated corn stover. Biotechnol Biofuels. 2014;7:72.

14. Palmqvist $E$, Hahn-Hägerdal B. Fermentation of lignocellulosic hydrolysates I: Inhibition and detoxification. Bioresour Technol. 2000;74:17-24.

15. Bokinsky G, Peralta-Yahya PP, George A, Holmes BM, Steen EJ, Dietrich J, Lee TS, Tullman-Ercek D, Voigt CA, Simmons BA, Keasling JD. Synthesis of three advanced biofuels from ionic liquid-pretreated switchgrass using engineered Escherichia coli. Proc Natl Acad Sci U S A. 2011;108:19949-54.

16. Frederix M, Mingardon F, Hu M, Sun N, Pray T, Singh S, Simmons BA, Keasling JD, Mukhopadhyay A. Development of an: E coli strain for one-pot biofuel production from ionic liquid pretreated cellulose and switchgrass. Green Chem. 2016;18:4189-97.

17. Xu F, Sun J, Konda NV, Shi J, Dutta T, Scown CD, Simmons BA, Singh S. Transforming biomass conversion with ionic liquids: Process intensification and the development of a high-gravity, one-pot process for the production of cellulosic ethanol. Energy Environ Sci. 2016;9:1042-9.

18. Brandt A, Ray MJ, To TQ, Leak DJ, Murphy RJ, Welton T. Ionic liquid pretreatment of lignocellulosic biomass with ionic liquid-water mixtures. Green Chem. 2011;13:2489-99. 
19. DeLong HC, Trulove PC, Haverhals LM, Reichert WM. U.S. Patent, 8,202,379, 2012.

20. Toledo Hijo AAC, Maximo GJ, Costa MC, Batista EAC, Meirelles AJA. Applications of lonic Liquids in the Food and Bioproducts Industries. ACS Sustain Chem Eng. 2016:4:5347-69.

21. Hulsbosch J, De Vos DE, Binnemans K, Ameloot R. Biobased lonic Liquids: Solvents for a Green Processing Industry? ACS Sustain Chem Eng. 2016;4:2917-31.

22. Jeong S, Ha SH, Lim MC, Kim SM, Kim YR, Koo YM, So JS, Jeon TJ. Elucidation of molecular interactions between lipid membranes and ionic liquids using model cell membranes. Soft Matter. 2012;8:5501-6.

23. Sharma VK, Mukhopadhyay R. Deciphering interactions of ionic liquids with biomembrane. Biophys Rev. 2018;10:721-34.

24. Pernak J, Kalewska J, Ksycińska H, Cybulski J. Synthesis and anti-microbial activities of some pyridinium salts with alkoxymethyl hydrophobic group. Eur J Med Chem. 2001;36:899-907.

25. Pernak J, Rogoza J, Mirska I. Synthesis and antimicrobial activities of new pyridinium and benzimidazolium chlorides. Eur J Med Chem. 2001;36:313-20.

26. Pernak J, Sobaszkiewicz K, Mirska I. Anti-microbial activities of ionic liquids. Green Chem. 2003;5:52-6.

27. Ranke J, Mölter K, Stock F, Bottin-Weber U, Poczobutt J, Hoffmann J, Ondruschka B, Filser J, Jastorff B. Biological effects of imidazolium ionic liquids with varying chain lengths in acute Vibrio fischeri and WST-1 cell viability assays. Ecotoxicol Environ Saf. 2004;58:396-404.

28. Couling DJ, Bernot RJ, Docherty KM, Dixon JNK, Maginn EJ. Assessing the factors responsible for ionic liquid toxicity to aquatic organisms via quantitative structure-property relationship modeling. Green Chem. 2006;8:82-90

29. Swatloski RP, Holbrey JD, Memon SB, Caldwell GA, Caldwell KA, Rogers RD. Using Caenorhabditis elegans to probe toxicity of 1-alkyl-3-methylimidazolium chloride based ionic liquids. Chem Commun. 2004;4:668-9.

30. Cvjetko Bubalo M, Hanousek K, Radošević K, Gaurina Srček V, Jakovljević T, Redovnikovic RI. Imidiazolium based ionic liquids: Effects of different anions and alkyl chains lengths on the barley seedlings. Ecotoxicol Environ Saf. 2014;101:116-23.

31. Gal N, Malferarri D, Kolusheva S, Galletti P, Tagliavini E, Jelinek R. Membrane interactions of ionic liquids: Possible determinants for biological activity and toxicity. Biochim Biophys Acta - Biomembr. 2012;1818:2967-74

32. Petkovic M, Ferguson JL, Gunaratne HQN, Ferreira R, Leitão MC, Seddon KR, Rebelo LPN, Pereira CS. Novel biocompatible cholinium-based ionic liquids-toxicity and biodegradability. Green Chem. 2010;12:643-64.

33. Wood N, Ferguson JL, Gunaratne HQN, Seddon KR, Goodacre R, Stephens GM. Screening ionic liquids for use in biotransformations with whole microbial cells. Green Chem. 2011;13:1843-51.

34. Hartmann DO, Pereira CS. Toxicity of lonic Liquids: Past, Present, and Future. In: Ionic Liquids in Lipid Processing and Analysis. Amsterdam: Elsevier; 2016. p. 403-421.

35. Stolte S, Matzke M, Arning J, Böschen A, Pitner WR, Welz-Biermann U, Jastorff B, Ranke J. Effects of different head groups and functionalised side chains on the aquatic toxicity of ionic liquids. Green Chem 2007:9:1170-9.

36. Stojanovic A, Morgenbesser C, Kogelnig D, Krachler R, Keppler BK. Quaternary Ammonium and Phosphonium Ionic Liquids in Chemical and Environmental Engineering. In: Ionic Liquids: Theory, Properties, New Approaches. 2011. p. 657.

37. EPA, List N: Disinfectants for Use Against SARS-CoV-2 (COVID-19), 2020.

38. Socha AM, Parthasarathi R, Shi J, Pattathil S, Whyte D, Bergeron M, George A, Tran K, Stavila V, Venkatachalam S, Hahn MG, Simmons BA, Singh S. Efficient biomass pretreatment using ionic liquids derived from lignin and hemicellulose. Proc Natl Acad Sci U S A. 2014;111:E3587-95.
39. Diez V Deweese A, Kalb RS, Blauch DN, Socha AM Cellulose Dissolution and Biomass Pretreatment Using Quaternary Ammonium lonic Liquids Prepared from H-, G-, and S-Type Lignin-Derived Benzaldehydes and Dimethyl Carbonate. Ind Eng Chem Res. 2019;58:16009-17.

40. Kim KH, Dutta T, Sun J, Simmons B, Singh S. Biomass pretreatment using deep eutectic solvents from lignin derived phenols. Green Chem. 2018;20:809-15.

41. Liu S, Das L, Blauch DN, Veronee C, Dou C, Gladden J, Sun N, Socha AM. Statistical design of experiments for production and purification of vanillin and aminophenols from commercial lignin. Green Chem. 2020;22:3917-26.

42. Kim KH, Eudes A, Jeong K, Yoo CG, Kim CS, Ragauskas A. Integration of renewable deep eutectic solvents with engineered biomass to achieve a closed-loop biorefinery. Proc Natl Acad Sci U S A. 2019;116:13816-24.

43. Kang A, Mendez-Perez D, Gog E-B, Baidoo EEK, Benites VT, Beller HR, Keasling JD, Adams PD, Mukhopadhyay A, Lee TS. Optimization of the IPP-bypass mevalonate pathway and fed-batch fermentation for the production of isoprenol in Escherichia coli. Metabol Eng. 2019;56:85-96.

44. USEPA. Methods for measuring the acute toxicity of effluent and receiving waters to freshwater and marine organisms, 5th ed. EPA 821-R-02012. 2002

45. OECD guideline for testing of chemicals. Daphnia sp., acute immobilization test and reproduction test. 1984.

46. Eike DM, Brennecke JF, Maginn EJ. Predicting melting points of quaternary ammonium ionic liquids. Green Chem. 2003;5:323-8.

47. Kostag M, Jedvert K, Achtel C, Heinze T, El Seoud OA. Recent advances in solvents for the dissolution, shaping and derivatization of cellulose: Quaternary ammonium electrolytes and their solutions in water and molecular solvents. Molecules. 2018;23:1-38.

48. Zhao B, Greiner L, Leitner W. Cellulose solubilities in carboxylate-based ionic liquids. RSC Adv. 2012:2:2476-9.

49. Raut DG, Sundman O, Su W, Virtanen P, Sugano Y, Kordas K, Mikkola JP. A morpholinium ionic liquid for cellulose dissolution. Carbohydr Polym. 2015;130:18-25.

50. Boukir A, Fellak S, Doumenq P. Structural characterization of Argania spinosa Moroccan wooden artifacts during natural degradation progress using infrared spectroscopy (ATR-FTIR) and X-Ray diffraction (XRD). Heliyon. 2019:5:e02477.

51. Ciolacu D, Ciolacu F, Popa V. Amorphous cellulose - Structure and characterization. Cell Chem Technol. 2011:45:13-21.

52. Liu R, Zhang J, Sun S, Bian Y, Hu Y. Dissolution and recovery of cellulose from pine wood bits in ionic liquids and a co-solvent component mixed system. J Eng Fiber Fabr. 2019;14:1-7.

53. He P, Liu H, Li Z, Liu Y, Xu X, Li J. Electrochemical deposition of silver in room-temperature ionic liquids and its surface-enhanced Raman scattering effect. Langmuir. 2004;20:10260-7.

54. Hora PI, Pati SG, McNamara PJ, Arnold WA. Increased use of quaternary ammonium compounds during the SARS-CoV-2 pandemic and beyond: Consideration of environmental implications. Environ Sci Technol Lett. 2020;7(9):622-31

55. Garcia MR, Cabo ML. Optimization of E coli inactivation by benzalkonium chloride reveals the importance of quantifying the inoculum effect on chemical disinfection. Frontiers Microbiol. 2018:9(1259):1-14.

56. USEPA, Ecological Effects Test Guidelines OCSPP 850.1010: Aquatic Invertebrate Acute Toxicity Test, Freshwater Daphnids. EPA 712-C-16-013. 2016.

\section{Publisher's Note}

Springer Nature remains neutral with regard to jurisdictional claims in published maps and institutional affiliations. 